\title{
The semiotic phenomenology of Maurice Merleau-Ponty and Michel Foucault
}

\author{
Richard L. Lanigan \\ International Communicology Institute, Southern Illinois University \\ SPCM Dept. MC 6605, Carbondale, Illinois 6290-1-6605,USA \\ e-mail: rlanigan@siu.edu
}

\begin{abstract}
Postmodern methodology in the human sciences and philosophy reverses the Aristotelian laws of thought such that (1) non-contradiction, (2) excluded middle, (3) contradiction, and (4) identity become the ground for analysis. The illustration of the postmodern logic is Peirce's (1) interpretant, (2) symbol, (3) index, and (4) icon. The thesis is illustrated using the work of Merleau-Ponty and Foucault and the le même et l'autre discourse sign where the ratio [Self:Same :: Other:Different] explicates the communicology of Roman Jakobson in the conjunctions and disjunctions, appositions and oppositions of discours, parole, langue, and langage.
\end{abstract}

\section{The problematic of identity}

The problematic with which we are confronted, the "concept of identity", is an ancient one with many testimonies in both Eastern and Western philosophies. In the West, the notion of identity is foundational in Aristotle and yet, it is turned on its head in Postmodernity (Lanigan 1995a, b). Following the foundational work in semiotic phenomenology of Charles Sanders Peirce (1931-1958) and Ernst Cassirer $(1923 ; 1979 ; 1995)$, Postmodernity deals with the symbolic world of culture in which the Aristotelian model of a natural world logic is turned on it head. In short, Aristotle's "law of thought" are questioned, found to be inappropriate to human experience, reversed in sequence and reformulated as positive constitutions. Lest the 
modern reader be lost in this postmodern move, I shall begin my analysis by staying with the Aristotelian statement of the laws of logic, with one exception. I shall reverse the order of the four laws, beginning with Aristotle's fourth, then, third, second, and first. This step allows us to approach the postmodern problematic by asking if there is a paradigm conscious experience that contradicts the Law(s) and thematically suggests what a positive statement of that Law(s) would be.

The Aristotelian logic of (1) formations (experiences) constituting (2) transformation (consciousness) is reversed such that consciousness (logic transformations) constitutes experience (logic formations) in the first instance. This to say that in the symbolic cultural world, logic transformations lead to formations (consciousness experience) which are the subject matter and process of the Human Sciences such that consciousness is formed by the rule sequence: (Postmodern 1; Aristotle 4) Law of Non-Contradiction [a thing cannot at once be and not be; a statement cannot be true and false at the same time], (Postmodern 2; Aristotle 3) Law of Excluded Middle [a thing must be or not be; a statement must be either true or false), (Postmodern 3; Aristotle 2) Law of Contradiction [one thing is not another thing; a statement is different from other statements], and (Postmodern 4; Aristotle 1) Law of Identity [one thing is only one thing; a statement is a statement].

In short, Aristotle's logic is constructed by moving from (1) to (4) as the "classical laws of thought". ${ }^{1}$ Later on in the philosophy of

The name "laws of thought" was developed in the middle ages to describe the three basic formation rules that Aristotle uses to construct the transformation rules of his famous syllogism or logic of propositions. A typical textbook on logic (Schipper, Schun 1959: 375-376) will explain that Aristotle has three propositional rules: (1) Identity, (2) Excluded Middle, and (3) Contradiction [also conflated as "Non-Contradiction"]. These qualitative rules derive from the combination of four quantitative types of propositions: (1) Universal Affirmative, (2) Universal Negative, (3) Particular Affirmative, and (4) Particular Negative. Both universal affirmative and universal negative propositions are examples of the Identity rule, they just have a different numerical valence (positive or negative signification). All logicians know this.

However, non-logicians worry about the ontology of valences. They start with (1) Identity where " $a=a$ ", then (2) go to the Contradiction of " $a$ " where "no a = b", then (3) in excluded Middle, they choose between either "a or not a" [knowing "not a" can be "b" or anything else as an interpretant of Step 2!], and then (4) they can see that you cannot have it both ways, that is, you cannot have both "a" and 
science, Leibniz extends the Aristotelian logic to cover all possible worlds, not just the natural world of experience on Earth. Much of the Postmodern view in Culture can be attributed to the constant need by old school (Modernist, Rationalist) positivists to modify Aristotle's logic as it applies to current mathematical logic in science.

To focus the postmodern problematic, we need to restate the logic transformation as they are affirmatively used by Postmodernists like Cassirer, Peirce, Merleau-Ponty, and Foucault to make positive constitutions of described conscious experience in the world of communication and culture. The Postmodern Logic Propositions listed below are stated in an inclusion order of constitution:

\section{Phenomenological Law of Non-Contradiction - a thing can at once} be and not be; a statement can be both true and false at the same time.

Eidetic/Empirical example: an interpretant (Peirce 1931-1958).

The eidetic and empirical example here is human embodied consciousness that is a sign of a sign, what Husserl calls "intentionality". Or even more simply as an example, take an oral/written/visual image, which is and is not a statement/sentence/proposition that Michel Foucault made into a famous semiotic example, namely, Magritte's painting L'usage de la parole (1928-1929): "This is not a pipe" plus the image of a pipe. In this example, the image refers to the sentence and vise versa (Lanigan 1992: 104). As Peirce (2.28) summarizes:

A sign, or representamen, is something which stands to somebody for something in some respect or capacity. It addresses somebody, that is, creates in the mind of that person an equivalent sign, or perhaps a more developed sign. That sign which it creates I call the interpretant of the first sign. The sign stands for something, its object. It stands for that object, not in all respects, but in reference to a sort of idea, which I have sometimes [e.g., 1.551] called the ground of the representamen. (Peirce 2.28; my bold emphasis, $R$. L.)

"not a" (the Law of Non-Contradition). Step (2) is a quantitative redundancy for logicians who thus have three laws of thought, but Step (2) is a qualitative embodied experience (ontology) for the rest of us who have four laws of thought. The ontological issue caused Aristotle to invent Enthymemes ("syllogisms" with a missing proposition supplied by the observer) and many other ontological (nonlogical) rules like the Law of Contradiction that are critical to Peirce's Postmodern version of Aristotle (Lanigan 1995b). 
2. Phenomenological Law of Excluded Middle - a thing must both be and not be; a statement must be both true and false. The Postmodern constitution of reflectivity.

Eidetic/Empirical example: a symbol (in C. S. Peirce's sense).

The eidetic and empirical example is a symbol of a sign (representation of a presentation). Writing is the the well know index of speaking. Peirce (2.247) specifies that "A Symbol is a sign which refers to the Object that it denotes by virtue of a law, usually an association of general ideas, which operates to cause the Symbol to be interpreted as referring to that Object." For example, Peirce (2.298) suggests, "Any ordinary word, as 'give,' 'bird,' 'marriage,' is an example of a symbol. It is applicable to whatever may be found to realize the idea connected with the word; it does not, in itself, identify those things."

3. Phenomenological Law of Contradiction - one thing is another thing; a statement is both the same as and different from other statements. The Postmodern constitution of reversibility.

Eidetic/Empirical example: an index (in C. S. Peirce's sense).

The eidetic and empirical example is the spatial locations of a sign such as an oral contract written down on paper, explicated in Roman Jakobson's theory of "redundancy features" (Lanigan 1992: 230). Peirce (2.247) says that "An Index is a sign which refers to its Object that it denotes by virtue of being really affected by that Object." "...And, it is not the mere resemblance of its Object, even in these respects which makes it a sign, but is the actual modification of it by the Object." Peirce's (2.285) example: "A rap on the door is an index. Anything which focuses the attention is an index."

4. Phenomenological Law of Identity - one thing is always another thing; a statement is another statement. The Postmodern constitution of reflexivity.

Eidetic/Empirical example: an icon (in C. S. Peirce's sense).

The eidetic and empirical example is the temporal location of a sign such as the "experience of consciousness" ("I made a mistake!") and the "consciousness of experience" ("I am alive!") explicated by Roman Jakobson's theory of "distinctive features" (Jakobson 1972: 43; Lanigan 1992: 230). As Peirce (2.247) notes, "An Icon is a sign which refers to the Object that it denotes merely by virtue of 
characters of its own, and which it possesses, just the same, whether any Object actually exists or not". "Anything whatever, be it quality, existent individual, or law, is an Icon of anything, in so far as it is like that thing and is used as a sign of it." Peirce's (2.275) relevant example is "any material image, as a painting." This very notion of the Icon is common knowledge among all the computer users of the world as a mere function of learning the difference between virtual images, memory images, and functions on the computer screen.

That the Aristotelian, Modernist concept of identity cannot be foundational is the positive thematic of Ernst Cassirer in his communicological turn in culture and in Charles Sanders Peirce's phenomenological turn in normative logics, i.e., semiotics. The rejected Modernist view of Aristotelian logic is also fundamental in Maurice Merleau-Ponty and his semiotic turn in phenomenology. That the concept of identity is the effect of understanding [rather than the cause Aristotle] is the thematic of Michel Foucault and his phenomenological turn in semiotics. To be explicit, the concept of identity is a logical function only insofar as it is derived from its ontological context of the embodied person (a phenomenology of phenomenology). The Postmoderns take the French view that the ontology of "Both the Self and the Other as Both the Same and Different" [le même et l'autre] constitutes the essence of human embodiment as:

(1) expression and perception in the consciousness of experience [the contribution of phenomenology]; and,

(2) the source of logical abstraction and phenomenological description in the experience of consciousness

[the contribution of semiotics].

The core domain of this Postmodern analysis is concisely articulated by Roman Jakobson (1972: 43): "The cardinal property of language noted by the initiator of semiotics, Charles Sanders Peirce (18391914), namely the translatability of any verbal sign into another, more explicit one, renders an effective service to communication in that it counteracts ambiguities caused by lexical and grammatical homonymy or by the overlapping of elliptic forms".

The task of explicating human communication as such a Postmodern ontology of both ambiguity in Merleau-Ponty and alterity in Foucault has its ground in the human science of Communicology 
(Lanigan 1997). Here, the fundamental focus is on the conjunctive theory and method of semiotic phenomenology at work in the semiosphere (Lotman 1990) where human communication (discourse) is, to use Merleau-Ponty's famous triadic formula, the reflectivity, reversibility, and reflexivity of culture (practice). The philosophy of communication explicated by Merleau-Ponty and Foucault will serve as a paradigmatic case as these themes of discourse and practice are applied in the French context. Before we can advance into the philosophic application of communication, however, we require a foundational understanding of how communication is viewed by Continental philosophers in general and by Merleau-Ponty and Foucault in particular.

\section{Roman Jakobson's theory of human communication}

Prerequisite to a grasp of contemporary Communication Theory (not machine instantiated Information Theory or Informatics) is a brief understanding of the theory advanced by Roman Jakobson. All contemporary discussion of communication derives from a fundamental understanding of Jakobson's work. It is no exaggeration to say that understanding the main positions and counter-positions of any contemporary author within the domain of the Philosophy of Communication is grounded in the use of Jakobson's definitional theory. It is certainly true that European philosophers of communication in the Continental tradition assume their readers, professional or lay, know the fundamental propositions demonstrated in the eidetic proofs and empirical demonstrations of Jakobson on the structure and function human communication. His theory work and applied research are preeminent as cited in the September 1972 journal issue of Scientific American.

Rather than a "theory" is the limited sense of a model, Jakobson's theory is a complete account of human communication from the microscopic to the macroscopic level of application. As such, Jakobson is the only person to have offered a legitimate Theory of Communication (illustrated in Fig. 1) with both eidetic and empirical application, i.e., a Communicology. The basic ELEMENTS of communication are capitalized in the diagram, while the Elements of communication are given in italics. While the logical and phenomeno- 
logical relations and correlations of this theory are worked out in great detail (Lanigan 1992: 229-236; 1997), our present discussion must be limited to this brief version.

\author{
CONTEXT \\ [Referential / Cognitive] \\ MESSAGE \\ [Poetic]
}

ADDRESSER

ADDRESSEE

[Emotive /Expressive] [Conative/Interpretive]

CONTACT

[Phatic]

CODE

[Metalinguistic / Glossing]

Figure 1. Roman Jakobson's (1960) theory of communication.

In Jakobson's theory, each element is contextual to the rest in binary (logical) pairs (phenomenological) and the system of pairs constitutes a Function. For example, in the poetic function of the Message, there are four relations for the Addresser (Ar) and Addressee (Ae) pair, namely, (1) Ar to Ar [Self embodiment). (2) Ae to Ae (Other embodiment), (3) Ar to Ae (thetic intentionality), and (4) Ae to Ar (Operative intentionality). Similar binary pairs exist for Context and Contact, and, for Message and Code. The poetic function per se is the rule of reversibility in which any syntagmatic category (i.e., a horizontal line of categories) can interchange with a paradigmatic category (i.e., a vertical line of categories). We need not work our way through all the relational possibilities for the formation of categories. C. S. Peirce has already done it for us and there are sixty-four (64) non-redundant categories, the basic three of interest to us being already mentioned: Symbol, Index, Icon. The discussion and illustration of the Jakobsonian categories as elements and functions is detailed in Lanigan (1992: 229-236).

It is important, as a matter of context, to note that the Addresser/ Addressee relationship and it four functions (emotive, expressive, 
conative, interpretive) are experienced as four network levels of communication transaction in human comportment. Demonstrated in the foundational work of Jürgen Ruesch, Semiotic Approaches to Human Relations (1972 reprint ed.), then Jürgen Ruesch and Gregory Bateson in Communication: The Social Matrix of Psychiatry (1951: 277), the commonly accepted networks of human discourse are (1) the Intrapersonal Level (or psychiatric/aesthetic domain of emotive communication) where the Addresser and Addressee may be one person whose communication is thought, emotion, etc.; (2) the Interpersonal Level (or social domain of expressive communication) in which the two person dyad is an example of behavioral exchange; (3) the Group Level (or cultural domain of conative communication) where an Addresser, one person, communicates with a group (an egocentric culture like the USA), or, the reverse context (a sociocentric culture like P. R. China) where a group as the Addresser influences an addressee, one person; and (4) the Intergroup Level (or transcultural domain of interpretive communication) in which one group addresses another group with such consequences as war, peace, the diffusion of innovation, and so on. In short, these four interconnected network levels contain the communicological process outlined by Roman Jakobson's theory of human communication. Historically speaking, the coincidence of this research and theory work accomplished by Ruesch, Bateson, and Jakobson in the early 1950 established the academic discipline of Communicology (human communication) in American universities.

Let me now briefly define each communication Element by it corresponding Function as a way of glossing Jakobson's (1960) Theory of Communication and its relevant parts. The Addresser is the human, embodied origin of communication and in consequence is not a mechanical "sender" or "signal source", but the expressive constitution of emotion. In linguistic terms, the Addresser is the verbal 1st Person (persona) who is speaking. The person may be the psychic voice the Greeks called mythos, or the persona whose oral speaking is audible as the interpretant logos of a person. As such, the Addresser gives (data) a Message that constitutes a Code and selects a Context for Contact ("choice of context" or analogue logic). Lotman (1990: 22) provides a detailed analysis of the motivation that occurs between message and code, code and message, in the formation of discourse as practice, communication as culture. 
The Addressee element of communication is basically the reverse phenomenological intentionality of the Addresser. The Addressee is the human, embodied origin of culture and in consequence is not a mechanical "receiver" or "signal destination", but the interpretive constitution of conation. In linguistic terms, the Addressee is the verbal 2nd Person (persona) who is spoken to. The person for whom oral listening is audible becomes the interpretant logos for the psychic voice the Greeks called hexis, or the embodied practice of culture. As such, the Addressee takes (capta) a Code that constitutes a Message and selects a Contact for Context ("context of choice" or digital logic).

Context is the referential function of the communicative act in which signification is denotive within a cognitive system of meaning. In linguistic terms, Context is the 3rd person, someone or something spoken of. It is crucial to recall that Jakobson rejects Saussure's notion of an arbitrary sign (signifier in opposition to signified). Rather, Jakobson demonstrates that communication is a "choice of context" such that signs have a relative, but necessary, motivation to one another (signifier in apposition to signified). As Holenstein (1976: 157) explains Jakobson's use of Peircian semiotics, a sign's "own constitution reflects the relational structure of the thing represented". Hence, we have Peirce's preferred name for the sign as a representamen.

Contact is the phatic function operating in human communication such that a physical (interpersonal) and psychological (embodied, intrapersonal) connection is established between the Addresser and the Addressee. The best eidetic/empirical example in linguistics is the concept of an emblem. An emblem is the anthropologist's name for a word that stands in place of a gesture, or, the gesture that replaces a verbal message. The emblem is a sign with a culturally known interpretant that moves from (1) physical contact (signification) between Addresser and Addressee to (2) mutual psychic sharing (meaning).

The Message displays the phenomenology of the poetic function in communication. Rather than a mundane reference to poetry, the essence of poiesis is the shifting of verbal elements exterior to the system of language in which case you have rhetoric, or, interior to the language in which case you have poetic. While there is a long, detailed phonological analysis that is relevant at this point, we must be content to explain the poetic function in verbal communication as paradigmatic and syntagmatic reversal of words as units in sentences. 
For example, once you know the words in a sentence by grammatical function, any word in that category can replace any other word. In the sentence, "The cat ate the dog." you immediately see that if you are a dog lover the message can be reversed as "The dog ate the cat". Moreover, you immediately know that any noun in the sentence can be replaced by a pronoun, and, any verb can substitute for any other verb. The vertical (paradigmatic) and horizontal (syntagmatic) word shifts can be remembered as a whole set, what Jakobson calls the "Prague Prism" or ever expanding matrix (hence, the Ruesch and Bateson use of the "social matrix" in the subtitle of their book). Jakobson concludes that messages are unique in language because human speaking (parole) consists of: (1) a linguistic utterance, (2) language as an individual, private property, and (3) the individualizing, centrifugal aspect of language (where centrifugal means moving from individual out to group, from person into culture). Message interpretation relies on perceiving the diachronic ("then and there" historical sequences) of verbal or nonverbal usage. Egocentric cultures stress the importance of messages over codes, individuals over groups.

The concept of a Code entails the understanding of the metalinguistic or glossing function in communication. Every communication system, verbal or nonverbal, has both an object language (discourse about extralinguisitic entities) and a metalanguage (discourse about linguistic entities) that specify synchronic relationships ("here and now" existential moments). Linguists refer to this code phenomenon as "double articulation", since an utterance or gesture refers both to itself as an entity and beyond itself to its context in a system. Most people experience the complexity of the language code when they look up a word (message) in a dictionary (code) only to find themselves referred to other words (messages in the same code), thus acting to no avail in an unknown code. Jakobson also judges that codes are unique in language because social language (langue) consists of (1) linguistic norm, (2) language as supraindividual, social endowment, and (3) the unifying, centripetal aspect of language (where centripetal means moving from group to individual, from culture to person). Sociocentric cultures stress the importance of codes over messages, groups over individuals.

The conjunction of egocentric and sociocentric cultures and the people who communicate in them is thematic for Postmodern philo- 
sophers of communication. In particular, French semiotic phenomenology represented by Merleau-Ponty and Foucault focuses on the ontology of le même et l'autre: "Both the Self and the Other as Both the Same and Different". This ontological proposition built into a linguistic aphorism of French philosophy constitutes a specific explication of Roman Jakobson's theory of communication. Where human beings seek their identity with others in a shared lived-world, we inevitably confront the ambiguity of identity in the Self encountering that which is the Same - time and again. And, we confront the alterity of identity in the Other who is Different - home and away.

\section{Merleau-Ponty's thematic of embodied identity: ambiguity}

The essence of embodied identity constitutes ambiguity (explicated as Self consciousness/Same experience; see Fig. 2), as Merleau-Ponty reminds us in the Phenomenology of Perception.

I can remain within the sphere of absolute self-evidence only if I refuse to make any affirmation, or to take [capta] anything for granted, if, as Husserl has it, I stand in wonder before the world, and ceasing to be in league with it, I bring to light the flow of motivations which bear me along in it, making my life wholly aware of itself, and explicit. When I try to pass from this interrogative state to an affirmation, and a fortiori when I try to express myself, I crystallize an infinite collection of motives within an act of consciousness, I revert to the implicit, that is, to the equivocal and to the world's free play. My absolute contact with myself, the identity of being and appearance cannot be posited, but only lived as anterior to any affirmation. (Merleau-Ponty 1981: 295; my emphasis and insert, $R$. L.).

In one concise argument, Merleau-Ponty demonstrates that the Cartesian world built on Aristotelian thinking, in which the logic of experience dictates the constitution phenomenona, cannot apply to embodied consciousness. Furthermore, the Aristotelian ground of logic cannot be sustained inasmuch as identity (the experience perceived and expressed) is the effect, result of consciousness ("wonder before the world"), and not the cause. 


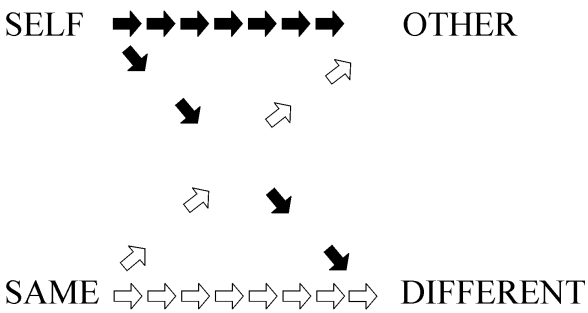

Legend: $\quad$ Consciousness (as parole parlante; corps propre):

Self-Other = Synecdoche: part $/$ whole* [parole]**

Same-Other $=$ Metaphor substance/whole [discours $]$

Experience (as parole parlée; corps veçu):

Same-Different = Metonymy: substance/attribute [langue]

Self-Different $\quad=$ Simile $[$ positive]; [langage] Irony [negative]: part/attribute

$\Rightarrow \Rightarrow \Rightarrow \Rightarrow \quad=$ "Self" combination

$\Rightarrow \Rightarrow \Rightarrow \Rightarrow \quad=$ "Same" combinations

Figure 2. Merleau-Ponty's ambiguity model (Lanigan 1992: 110).

* Note the respective syntagmatic relationships, e.g., Self $=$ part, Other $=$ whole, etc.

** Traditional linguistic descriptions.

For semiotic clarity in these complex phenomenological relations, I should point out that Figures 1 is an explication of consciousness of experience $[\mathbf{C}>\mathbf{E}]$ as a semiotic phenomenology of existential being that Husserl calls an "order of experience" [experiencer $>$ experiencing $>$ experienced]. In Fig. 2, the reverse reading which is the experience of consciousness $[\mathbf{E}>\mathbf{C}$ ] is what Husserl calls an "order of analysis" [experiencer < experiencing < experienced] (Lanigan 1992: 20). When the "order of experience" is assumed to match the "order of 
analysis" [i.e., no reflexivity, no reversibility, no reflectivity], then we have positive science. We have the positivististic, natural attitude assumption that posits the Cartesian, Aristotelian identity of appearances as "being", wherein consciousness and experience are erroneously hypostatized as paradigmatic equivalents (Jakobson's sense).

Figure 2 sketches the basic elements in Merleau-Ponty's use of the le même et l'autre model of identity as ambiguity in human communication and behavior. The background analysis for this model is found in Lanigan (1988; 1992; 1997).

At this point, let me only summarize the basic position that his many works suggest. Merleau-Ponty's major work on expression, Signs (1960), as well as his Phenomenology of Perception (1945), relate semiotics, the theory of signs (aesthetic, logical, social systems), to the phenomenology of embodiment (Jakobson's communication elements: context, message, contact, code, addresser, addressee). In his explication of both perception and expression, Merleau-Ponty suggests that there are two levels of discourse: (1) existential discourse in which a person expresses his or her speaking in an original and perceptive speech, that is a "speech speaking" (parole parlante) that proffers an authentic message and (2) empirical discourse where a person merely expresses what has already been said by others, i.e., a "speech spoken" (parole parlée) that legitimizes the social code. In the speech speaking case, there is a rhetorical function of identity where consciousness of experience is the original reference to existential meaning., i.e., the authentic act of expression that is the linguistic message embodied in the person (corps propre) as addresser (Jakobson 1960; 1971; Holenstein 1976).

First, Merleau-Ponty corrects Saussure's static notion of parole by making it the dynamic parole parlante or what Roman Jakobson calls the "message" in his parallel correction of Saussure. Second, MerleauPonty corrects the concept of langue by the more existential parole parlée or what Jakobson in agreement calls the "code". In this second category of speech spoken, the rhetorical function is banal (corps $v e c ̧ u$ ) and evokes an experience of consciousness, i.e., the commonplace meaning that is the linguistic code discovered by the addressee (Jakobson's sense).

Finally, let us note that Merleau-Ponty offers a major correction to the method of Husserl's phenomenology by stressing the importance 
of semiotics in the description of phenomena, the importance of structural analysis in defining (reducing) phenomena, and the importance of hermeneutic principles for the interpretation of phenomena. The three step method of Description, Reduction, and Interpretation is the result of his focus on the reversible, reflexive, and reflective relations between perception and expression - all of which are the foundation for Foucault's analysis of social embodiment and institutional comportment.

\title{
3. Foucault's thematic of embodied identity: alterity
}

The social essence of embodied identity constitutes alterity (explicated as Other consciousness/Different experience; see Fig. 2), as Foucault reminds us in Fearless Speech.

\begin{abstract}
When you accept the parrhesiastic game in which your own life is exposed, you are taking up [capta] a specific relationship to yourself; you risk death to tell the truth [parrhesia] instead of reposing in the security of a life where the truth goes unspoken. Of course, the threat of death comes from the Other, and thereby requires a relationship to the Other. But the parrhesiates primarily chooses a specific relationship to himself: he prefers himself as truth-teller rather than as a living being who is false to himself. (Foucault 2001: 17; my emphasis and inserts, $R$. L.)
\end{abstract}

Figure 3 illustrates the basic components in Foucault's use of the le même et l'autre model of identity as alterity in human communication and behavior. Again, I note that the background analysis for this model is found in Lanigan (1988; 1992; 1997). Also note, in particular, that the model is essentially the same as presented in Fig. 2. Having said that, it is critically important to see that we are reversing directional relations by moving from the Other over to the Self, and from the Different over to the Same. This movement is stressed in the presentation of the Legend information given in Fig. 3.

Michel Foucault's Les mots et les choses [Words and Things] (1966), intentionally retitled by him for its English translation as The Order of Things: An Archaeology of the Human Sciences, and it's appendix essay L'archéologie du savoir [The Archaeology of Knowledge (sic) < Understanding>, 1969] add a methodological dimension to Merleau-Ponty's view. Foucault argues that Merleau-Ponty's 
second, empirical code level of discourse (énonciation) that we know (connaissance) as the cultural code of social power hides the first, existential message level of "stating" discourse (énoncé) that we understand (savoir) as desire. This agonistic or contested process of rhetorical levels forms a "rupture" or ongoing discontinuity of discourses constructing and deconstructing one another in apposition [both are equally opposed to] to the embodied person.

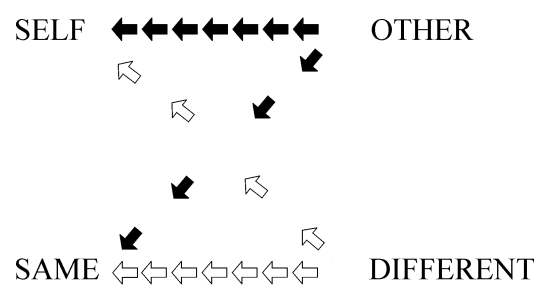

Legend: $\quad$ Consciousness (as énoncé; savoir):

$\begin{aligned} & \text { Other-Self } \\ & \text { [parole }]^{* *}\end{aligned}$
$\begin{aligned} & \text { Other-Same } \\ & \text { discours }]\end{aligned}$

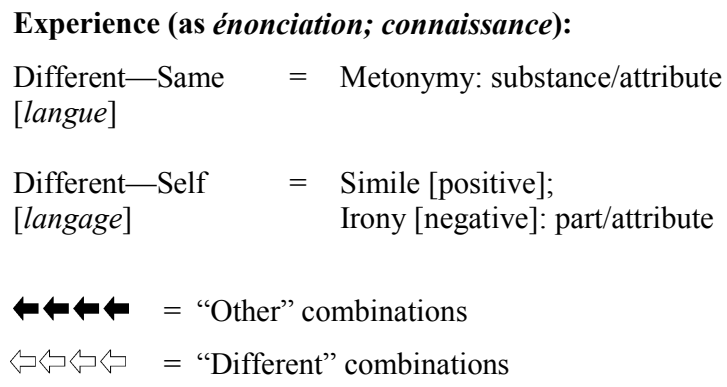

Figure 3. Foucault's alterity model (Lanigan 1992: 110).

* Note the respective syntagmatic relationships, e.g., Other $=$ part, Self $=$ whole, etc. ** Traditional linguistic descriptions. 
By using the method of (1) "archaeology" (one of Husserl's key concepts) or knowing (connaissance or knowing as the experience of consciousness; Jakobson's "horizontal" syntagmatic category of "code") and the method of (2) "genealogy" (savoir or understanding as the consciousness of experience; Jakobson's "vertical" paradigmatic category of "message"), Foucault engages his third level, which he names (3) "critical methodology" in his L'Ordre du discours (1971). Here, the "order of discourse" defines parrhesiastic rhetoric (Lanigan 1984). I should also make the relevant comment that in developing this three step methodology, Foucault begins with Edmund Husserl, as did Merleau-Ponty, and develops his three steps in parallel function to Merleau-Ponty's methodological steps of (1) Description, (2) Reduction, and (3) Interpretation. Clearly, both Merleau-Ponty and Foucault account for a systematic application of semiotic phenomenology to existential perception (Merleau-Ponty) and social expression (Foucault).

Note that Foucault's archaeology is a method of "oppositions" or "exclusions" (Jakobson's "distinctive features"), while genealogy is a method of "interstices" or "ensemble" (Jakobson's "redundancy features"). This critical model subjects both archaeology and genealogy to one another as a dialectic of both opposition and apposition as Foucault's "reversal-principle" (Jakobson's "poetic function" of paradigmatic and syntagmatic interchange). Foucault is following Merleau-Ponty's prescription that the first step of analysis is a "phenomenology of phenomenology". That is, the conjunctions of both consciousness and experience in discourse are seen as reversible, reflexive, and reflective in judgment.

Hence, Foucault offers a critical approach to discourse viewed as a phenomenological semiotic (Husserl's "order of analysis") that completes Merleau-Ponty's approach of a semiotic phenomenology (Husserl's "order of experience"). In short, while Merleau-Ponty examines the place of personal perception in public expression (intentionality as as a message/code), Foucault critically studies the reverse, i.e., the place of public expression in personal perception (embodiment as a code/message) as illustrated, for example, in the narratology of his study of the hermaphrodite, Herculine Barbin.

By way of a brief conclusion, let me suggest that it is clear that where Merleau-Ponty is existential, Foucault is social. Where Merleau-Ponty interrogates perception, Foucault questions expression. 
Where Merleau-Ponty explores the ambiguity of the individual's comportment, Foucault journeys into the institutions of the group and the community as political actuality. Both thinkers are grounded in traditional axiology, stressing the aesthetics, logics, and politics of perception and expression, i.e., the worldview of Communicology in which semiotics and phenomenology are in a constant Postmodern dialectic of discourse and practice, habitus and hexis - to cite Bourdieu's parallel system of cultural analysis in the French milieu of the Postmodern human sciences. ${ }^{2}$

\section{References}

Cassirer, Ernst 1923. Philosophie der symbolischen Formen, 3 vols. Berlin: Bruno Cassirer.

- 1979. Symbol, Myth, and Culture: Essays and Lectures of Ernst Cassirer, 1935-1945. (Verene, Donald Phillip, ed.) New Haven: Yale University Press. [Italian trans., Simbolo, mito e cultura, Rome and Bari: Laterza, 1981; Japanese trans., Kyoto: Mionerva, 1985.]

- 1995. The Philosophy of Symbolic Forms. Vol. 4. The Metaphysics of Symbolic Forms. New Haven: Yale University Press.

Foucault, Michel 1966. Les Mots et les Choses. Paris: Éditions Gallimard. [See 1970.]

- 1969. L'Archéologie du Savoir. Paris: Éditions Gallimard. [See 1972.]

- 1970. The Order of Things: An Archaeology of the Human Sciences. London: Tavistock Publications.

- 1971. L'ordre du discours: Leçon inaugural au Collège de France. Paris: Éditions Gallimard.

- 1972. The Archaeology of Knowledge [sic; Understanding] and The Discourse on Language. (Smith, A. M. S., trans.) New York: Pantheon, Random House. [Combined one volume trans. of Foucault 1969 and 1971.]

- 1978. Herculine Barbin dite Alexina B. Paris: Éditions Gallimard. [See 1980.]

- 1980. Herculine Barbin: Being the Recently Discovered Memoirs of a Nineteenth-Century French Hermaphrodite. (McDougall, R., trans.) New York: Pantheon.

2 An abstracted version of this paper was presented as a lecture at the 8 th Congress of the International Association for Semiotic Studies, Universite Lumière, Lyon 2, July 7-12, 2004, Lyon, France. An extended version is forthcoming as "Communicology: The French tradition in human science" in Perspectives on the Philosophy of Communication, ed. Pat Arneson (West Lafayette: Purdue University Press, in press for 2007). 
- 2001 [1983]. Fearless Speech. (Pearson, Joseph, ed.) Los Angeles: Semiotext(e).

Holenstein, Elmar 1976. Roman Jakobson's Approach to Language: Phenomenological Structuralism. (Schelbert, C.; Schelbert, T., trans.) Bloomington: Indiana University Press.

Jakobson, Roman 1960. Closing statement: Linguistics and poetics. In: Sebeok, Thomas A. (ed.), Style in Language. Cambridge: The M.I.T. Press, 350-377.

- 1971 [1950]. Linguistics and communication theory. In: Jakobson, Roman, Selected Writings: Vol. II, Word and Language. The Hague: Mouton, 570579.

- 1972. Verbal communication. In: Flanagan, Dennis et al. (eds.), Communication. (A Scientific American Book.) San Francisco: W. H. Freeman and Co., 37-44. [First published in the September 1972 issue of Scientific American.]

Lanigan, Richard 1984. Semiotic Phenomenology of Rhetoric: Eidetic Practice in Henry Grattan's Discourse on Tolerance. Washington: Center for Advanced Research in Phenomenology and University Press of America.

- 1988. Phenomenology of Communication: Merleau-Ponty's Thematics in Communicology and Semiology. Pittsburgh: Duquesne University Press.

- 1992. The Human Science of Communicology: A Phenomenology of Discourse in Foucault and Merleau-Ponty. Pittsburgh: Duquesne University Press.

- 1995a. The postmodern ground of communicology: Subverting the forgetfulness of rationality. The American Journal of Semiotics 11(1-2): 5-21.

- 1995b. From enthymeme to abduction: The classical law of logic and the postmodern rule of rhetoric. In: Langsdorf, Lenore; Smith, Andrew R. (eds.), Recovering Pragmaticism's Voice: The Classical Tradition, Rorty, and the Philosophy of Communication. Albany: State University of New York Press, 49-70; (notes) 278-283.

- 1997. 'Communicology' and 'Structuralism'. In: Embree, Lester et al. (eds.), Encyclopedia of Phenomenology. Boston: Kluwer Academic Publishers, 104110, 683-689.

Lotman, Yuri 1990. Universe of the Mind: A Semiotic Theory of Culture. Bloomington: Indiana University Press.

Merleau-Ponty, Maurice 1964 [1960]. Signs. (McCleary, Richard C., trans.) Evanston: Northwestern University Press.

- 1981 [1945]. Phenomenology of Perception. (Smith, Colin, trans.; with corrections by Forrest Williams and David Guerrière.) London: Routledge.

Peirce, Charles Sanders 1931-1958. Collected Papers of Charles Sanders Peirce. [CP] Vol. 1: Principles of Philosophy; Vol. 2: Elements of Logic; Vol. 3: Exact Logic (Published Papers); Vol. 4: The Simplest Mathematics; Vol. 5: Pragmatism and Pragmaticism; Vol. 6: Scientific Metaphysics; (Hartshorne, Charles; Weiss, Paul, eds.) (1931-1935); Vol. 7: Science and Philosophy; Vol. 8: Reviews, Correspondence, and Bibliography. (Burks, Arthur W., ed.) (1958). Cambridge: Harvard University Press. 
Ruesch, Jürgen 1972. Semiotic Approaches to Human Relations. The Hague:

Mouton. [Reprint of Ruesch's collected articles and books in one volume.]

Ruesch, Jürgen; Bateson, Gregory 1951. Communication: The Social Matrix of Psychiatry. New York: W. W. Norton. [Reprint editions 1968, 1987.]

Watson, Edith; Schuh, Edward 1959. A First Course in Modern Logic. New York:

Henry Holt.

\section{Семиотическая феноменология Мориса Мерло-Понти и Мишеля Фуко}

Постмодернистская методология в гуманитарных науках и в философии отворачивается от законов мышления Аристотеля, где (1) непротиворечивость, (2) исключенное третье, (3) противоречивость и (4) тождество становятся основой анализа. Примером постмодернистской логики служат пирсовские (1) интерпретант, (2) символ, (3) индекс, и (4) икон. Этот тезис автор иллюстрирует с помощью работ Мерло-Понти и Фуко, используя знак дискурса le même et l'autre, где соотношение [Сам: Такой же :: Другой: Отличающийся] эксплицирует теорию коммуникации Якобсона как коньюнкции и дизъюнкции, апозиции и оппозиции терминов discours, parole, langue и langage.

\section{Maurice Merleau-Ponty ja Michel Foucault' semiootiline fenomenoloogia}

Postmodernne metodoloogia humanitaarteadustes ja filosoofias pöördub ära aristotellikest mõtlemisseadustest, milleks on (1) mittevasturääkivus, (2) välistatud kolmas, (3) vasturääkivus, ja (4) samasus kui analüüsi alus. Postmodernse loogika näiteks on Peirce'i (1) tõlgend, (2) sümbol, (3) indeks, ja (4) ikoon. Seda väidet illustreeritakse Merleau-Ponty ja Foucault töödega ning le même et l'autre diskursusemärki kasutades, kus suhe [Ise:Sama :: Teine:Erinev] eksplitseerib Roman Jakobsoni kommunikoloogia kui discours, parole, langue, ja langage konjunktsioonid ja disjunktsioonid, apositsioonid ja opositsioonid. 